Kemudi: Jurnal Ilmu Pemerintahan | 167

Volume 05 Nomor 02 Februari 2021

2622-9633 (Online)

Open Access at: https://ojs.umrah.ac.id/index.php/kemudi

DOI: https://doi.org/10.31629/kemudi.v5i02.2773

\title{
Potensi Masalah Pilkada Serentak 2020 dan Kekhawatiran Masyarakat Pemilih Muda
}

\section{Reka Bayu Pramana}

Program Studi Teknologi Pascapanen

Sekolah Ilmu dan Teknologi Hayati, Institut Teknologi Bandung (ITB)

*rekabayupramana@gmail.com

\section{Fatur Rahman}

Program Studi Teknologi Pascapanen Sekolah Ilmu dan Teknologi Hayati, Institut Teknologi Bandung (ITB)

\section{Naura Pasya Karuza}

Program Studi Teknologi Pascapanen Sekolah Ilmu dan Teknologi Hayati, Institut Teknologi Bandung (ITB)

\section{Ryas Sulistyo Hanafi}

Program Studi Teknologi Pascapanen Sekolah Ilmu dan Teknologi Hayati, Institut Teknologi Bandung (ITB)

\section{Aulia Azmi Nur Rahmani}

Program Studi Teknologi Pascapanen Sekolah Ilmu dan Teknologi Hayati, Institut Teknologi Bandung (ITB)

\author{
Nisrina Qoulan Tsaqila \\ Program Studi Teknologi Pascapanen \\ Sekolah Ilmu dan Teknologi Hayati, \\ Institut Teknologi Bandung (ITB)

\section{Latiefah Zuhra Daulay} \\ Program Studi Teknologi Pascapanen \\ Sekolah Ilmu dan Teknologi Hayati, \\ Institut Teknologi Bandung (ITB)
}

\begin{abstract}
ABSTRAK
Dalam negara demokrasi pemilu merupakan suatu kewajiban, namun di tengah situasi pandemi terdapat potensi munculnya masalah yang dapat mencederai substansi demokrasi itu sendiri. Tujuan dilakukannya penelitian ini adalah memetakan kekhawatiran masyarakat dengan kelompok usia 19-24 tahun terhadap masalah demokrasi Indonesia pada masa pandemi serta mengelaborasikannya. Metode yang digunakan dalam penelitian ini adalah survei terkait Pilkada 2020 yang dilakukan pada 100 responden. Survei terdiri
\end{abstract}


dari tingkat pengetahuan mengenai teknis Pilkada,tingkat antusiasme masyarakat, dan kekhawatiran terhadap potensi masalah Pilkada 2020. Berdasarkan tingkat pengetahuan masyarakat akan teknis Pilkada 2020, diperoleh data bahwa responden sebanyak $32 \%$ tidak mengetahui sama sekali mengenai sistem maupun teknis pelaksanaan Pilkada 2020,50\% responden sedikit mengetahui teknis pelaksanaan Pilkada, dan $18 \%$ responden telah mengetahui teknis pelaksanaan Pilkada. Berdasarkan tingkat antusiasme masyarakat terhadap Pilkada 2020, diperoleh data bahwa sebanyak $45 \%$ responden belum memutuskan akan melakukan pencoblosan atau tidak, 40\% akan tetap melakukan pencoblosan, $12 \%$ tidak peduli dengan pelaksanaan pilkada, dan 3\% menyatakan tidak akan melakukan pencoblosan karena takut terhadap penularan virus Covid-19. Berdasarkan tingkat kekhawatiran masyarakat terhadap potensi timbulnya masalah baru dalam Pilkada 2020, diperoleh data bahwa responden sebanyak $76 \%$ orang khawatir akan praktik money politic berkedok bantuan Covid-19, 69\% khawatir akan muncul cluster virus baru, $68 \%$ khawatir terhadap berkurangnya jumlah pemilih, dan $11 \%$ sisanya khawatir akan permasalahan lain. Dengan mengidentifikasi dan mengelaborasikan potensi masalah, maka memungkinkan dilakukannya tindakan preventif sehingga kerugian yang disebabkan oleh permasalahan terkait dapat diminimalisir.

Kata Kunci: Pilkada 2020, Pandemi, Demokrasi

\section{Pendahuluan}

Diadakannya pemilihan kepala daerah (Pilkada) merupakan sarana pelaksanaan kedaulatan rakyat di tingkat daerah. Dasar yuridis pelaksanaan Pilkada didasarkan pada pasal 1 PP no.6 tahun 2005. Dalam pelaksanaannya, Pilkada diselenggarakan oleh KPU tingkat daerah (provinsi dan kabupaten/kota) diawasi oleh panwaslu (panitia pengawas pemilihan umum) tingkat daerah. Pilkada hakikatnya merupakan pesta demokrasi demi mewujudkan harapan rakyat. Penyelenggaraan pemilu dan pilkada merupakan salah satu indikator berhasilnya demokrasi di sebuah negara (Azis, 2009). Namun, bersamaan dengan dilangsungkannya pesta demokrasi di tahun 2020 sedang terjadi pandemi Covid-19, hal ini mengakibatkan timbulnya kekhawatiran di masyarakat, Pada 24 September 2020, pelaksanaan tahapan pemilihan pilkada dikritik banyak pihak karena dalam perjalanannya dinilai kurang memperhatikan keselamatan dan masyarakat. pasalnya, bawaslu telah mencatat terjadi 234 pelanggaran protokol kesehatan selama masa pendaftaran bakal calon peserta pilkada. (Yuniar, 2020). Indonesia merupakan negara dengan bentuk piramida penduduk ekspansif, menurut data dari BPS, pada tahun 2019 jumlah penduduk Indonesia dengan usia 20-24 tahun adalah $21.917,6$ juta jiwa. dengan begitu dapat diproyeksikan bahwa kelompok usia tersebut memiliki porsi cukup besar sebagai pemilih pada pilkada 2020, pada 
paper ini dianalisis permasalahan dan kekhawatiran masyarakat mengenai pilkada serentak 2020 yang diwakili dengan responden dengan kelompok usia 19-24 tahun. Paper ini disusun berdasarkan studi kualitatif dan kuantitatif. Data kuantitatif diperoleh melalui survey secara daring dengan total responden sebanyak 100 orang. responden merupakan warga negara indonesia dengan kelompok umur 19-24 tahun dengan domisili DKI Jakarta, Jawa Barat, Jawa Tengah, Jawa Timur, Banten, DIY Yogyakarta, Sumatera Barat, Sumatera Utara, Sumatera Selatan, Kalimantan Tengah, Kalimantan Timur, Kepulauan Riau, Bengkulu. Data hasil perolehan kemudian dianalisis menggunakan microsoft excel kemudian diinterpretasikan dengan mengaitkannya pada data kualitatif. Data dan argumentasi kualitatif didasarkan pada berbagai sumber referensi ilmiah seperti jurnal dan paper, serta berita media massa mengenai pilkada serentak 2020.

\section{Tinjauan Pustaka}

Praktik money politic atau politik uang di Indonesia sudah menjadi rahasia umum dan lumrah dilakukan. Yang dimaksud politik uang adalah, uang yang ditujukan dengan maksud-maksud tertentu seperti contohnya untuk melindungi kepentingan bisnis dan kepentingan politik tertentu. Politik uang bisa juga terjadi ketika seorang kandidat membeli dukungan parpol tertentu atau membeli suara dari pemilih untuk memilihnya dengan iming-iming imbalan yang bersifat finansial. Politik uang bisa juga terjadi ketika pihak penyandang dana berkepentingan bisnis maupun politik tertentu. Bentuknya bisa berupa uang, namun bisa pula berupa bantuan-bantuan sarana fisik pendukung kampanye pasangan kandidat tertentu (Lesmana, 2011).

Jumlah pemilih pada Pilkada tahun ini kemungkinan akan mengalami penurunan yang cukup signifikan dikarenakan adanya pandemi. Pelaksanaan Pilkada yang mengharuskan masyarakat bertemu dengan kerumunan orang (meski dengan memperhatikan protokol kesehatan) membuat masyarakat merasa khawatir akan tertular Corona (Fitria et al., 2020). Apatisme yang sering terjadi pada proses Pilkada (Ardiyanti \& Julian, 2018) juga akan meningkat disebabkan fokus masyarakat saat ini adalah memperbaiki serta mempertahankan kestabilan ekonomi sebagai salah satu sektor paling terdampak dari adanya pandemi ini (Nasution et al., 2020). Meskipun teknis pelaksanaan pilkada tetap memperhatikan protokol kesehatan, masih terdapat kemungkinan penyebaran khususnya pada panitia (Kennedy et al., 2020). Orang pengidap penyakit kronis pun memiliki angka kematian yang lebih tinggi (Susilo et.al ,2020). Dengan melakukan pilkada, hak memilih dalam pemilihan 
kepala daerah dapat tercapai berdasarkan perpu No. 2 tahun 2020. Namun hak atas kesehatan juga tidak kalah penting dalam pelaksanaan pilkada ini. Apabila pemerintah Ialai dalam menjaga, konsekuensi salah satunya adalah bertambahnya kasus Covid-19 yang lebih signifikan. Sehingga pelaksanaannya harus benar-benar ketat dan diperlukan kerja sama antara masyarakat dan pemerintah untuk mencapai pilkada dengan protokol yang baik dan benar (Kennedy et al., 2020).

\section{Metode Penelitian}

Penelitian ini merupakan penelitian kualitatif yang mencakup dua maksud penetapan fokus penelitian. Pertama, penetapan fokus penelitian adalah upaya untuk membatasi studi. Kedua, penetapan fokus berfungsi sebagai kriteria inklusi-ekskluasi, sehingga memudahkan dalam memilah mana data yang sesuai dan mana yang tidak, dengan begitu peneliti tidak dipusingkan dengan datum-datum (meskipun mungkin menarik bagi peneliti) yang terlalu banyak yang pada gilirannya akan mempersulit peneliti sendiri dalam menganalisis data. Lebih lanjut, dalam penelitian kualitatif, fokus penelitian bersifat tentatif atau sementara, artinya bisa jadi fokus penelitian berubah ketika peneliti menemukan hal yang menarik di lapangan (Moleong, 1989).

Penelitian ini menggunakan metode studi kasus yang berusaha menggambarkan, menjelaskan dan menganalisis fenomena, peristiwa, aktivitas, kepercayaan, persepsi dan pemikiran secara individual dan kelompok. Dengan metode studi kasus, maka fakta mengenai masalah dan fokus penelitian dari berbagai sumber data akan digali, dianalisis dan diinterpretasikan untuk mengangkat substansi mendasar yang terdapat dibalik kasus yang diteliti. Studi kasus adalah suatu pendekatan yang digunakan untuk mempelajari, menerangkan, atau menginterpretasikan suatu kasus dalam konteksnya secara natural tanpa ada intervensi dari pihak luar. Sehingga yang membedakan metode studi kasus dengan metode penelitian kualitatif lainnya adalah mengenai kedalaman analisis pada kasus yang spesifik.

Penelitian ini berlokasi di Desa Bejiharjo Kec. Karangmojo, Kab. Gunung Kidul, Yogyakarta. Lokasi penelitian ini dipilih sebab terdapat fenomena menarik pada salah satu objek wisata di Bejiharjo yaitu Objek Wisata Goa Pindul yang menimbulkan polemik perebutan sumber daya yang ada. Data 
penelitian ini terdiri dari data primer dan data sekunder. Berikut adalah sumber data dalam penelitian ini yang terdiri dari dua jenis, yaitu:

\section{a) Informen Penelitian}

Informen penelitian termasuk kedalam data primer. Data primer adalah data yang diperoleh langsung dari informan penelitian dengan proses wawancara yang dijadikan objek penelitian. Data tersebut diperoleh dari hasil wawancara mendalam dengan informen tersebut. Informan penelitian merupakan orang yang menjadi sumber data dalam penelitian yaitu pokdarwis di Goa Pindul Kabupaten Gunung Kidul.

Teknik pemilihan informan dalam penelitian ini yaitu menggunakan teknik purposive. Teknik purposive merupakan teknik mengambilan sumber data dengan pertimbangan tertentu, orang yang dianggap paling tahu tentang permasalahan yang diteliti atau orang yang berkedudukan sebagai penguasa sehingga memudahkan peneliti untuk memahami obyek serta situasi sosial yang diteliti.

b) Dokumen Penelitian

Dokumen penelitian termasuk kedalam jenis data sekunder. Data sekunder yaitu data yang diperoleh dari lembaga atau instansi yang berwenang, berita dari surat kabar, dan dokumen-dokumen terkait lainnya.

Teknik pengumpulan data pada penelitian ini dilakukan melalui teknik observasi, wawancara mendalam, dokumentasi. Kemudian hal terakhir yang dilakukan adalah analisis data terhadap temuan substantif maupun temuan formal. Analisis data menjadi sebuah kegiatan yang dilakukan untuk mengatur, mengurutkan, mengelompokkan, memberi kode/tanda, dan mengkategorikan data sehingga diperoleh temuan yang sesuai dengan masalah yang ingin dijawab. Analisis data dalam penelitian kualitatif adalah proses mencari dan menyusun secara sistematis data yang diperoleh dari hasil wawancara, catatan lapangan dan dokumentasi, dengan cara mengorganisasikan data ke dalam kategori, menjabarkannya ke dalam unit-unit, melakukan sintesa, menyusun ke dalam pola, memilih mana yang penting untuk dipelajari dan membuat kesimpulan. Dengan begitu, data akan mudah dipahami oleh peneliti sendiri maupun orang lain (Sugiyono, 2006).

\section{Pembahasan}


Berdasarkan hasil survei terhadap 100 orang mengenai pelaksanaan Pilkada 2020 diperoleh hasil bahwa sebanyak 32 orang responden (32\%) tidak mengetahui sama sekali mengenai sistem maupun teknis pelaksanaan Pilkada 2020, 50 orang responden (50\%) sedikit mengetahui teknis pelaksanaan Pilkada, dan 18 orang (18\%) telah mengetahui teknis pelaksanaan Pilkada (gambar 1). Hasil survei tingkat antusiasme masyarakat terhadap pelaksanaan Pilkada serentak menunjukkan sebanyak 45 orang (45\%) belum memutuskan akan melakukan pencoblosan atau tidak, 40 orang (40\%) akan tetap melakukan pencoblosan, 12 orang (12\%) tidak peduli dengan pelaksanaan pilkada, dan 3 orang (3\%) menyatakan tidak akan melakukan pencoblosan karena takut terhadap penularan virus Covid-19 (gambar 2). Sedangkan hasil survei mengenai kekhawatiran masyarakat terhadap masalah yang muncul akibat dilaksanakannya Pilkada menunjukkan bahwa dari 100 orang, 76 orang khawatir politik uang yang kerap terjadi akan semakin mudah dilakukan oleh oknum masyarakat dengan mengatasnamakan bantuan Covid-19, 69 orang khawatir akan munculnya cluster virus baru, 68 orang mengkhawatirkan akan berkurangnya jumlah pemilih sebagai bentuk respons ketakutan akan tertular virus, dan 11 orang lain menyatakan kekhawatiran atas kemunculan masalah lain seperti hilangnya kepercayaan masyarakat terhadap pemerintah terkait keseriusan dalam penanganan pandemi, timbulnya kecurangan yang terjadi akibat mengambil celah yang ada di prosedur pemilu saat pandemi ini seperti manipulasi jumlah surat suara, dan meningkatnya jumlah sampah akibat alat coblos sekali pakai (gambar 3 ).

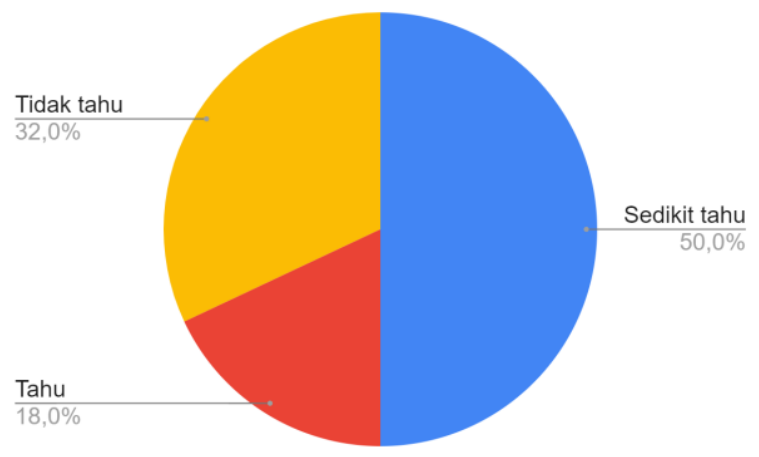

Gambar 1. Persentase pengetahuan responden mengenai teknis Pilkada serentak 2020 


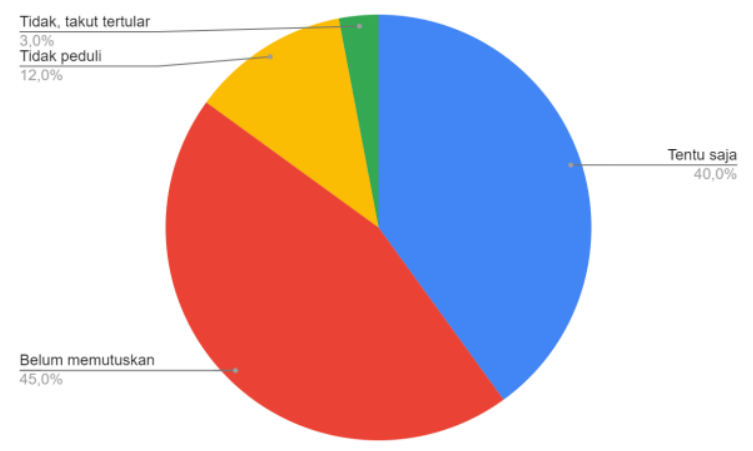

Gambar 2. Persentase antusiasme masyarakat terhadap pelaksanaan Pilkada serentak 2020

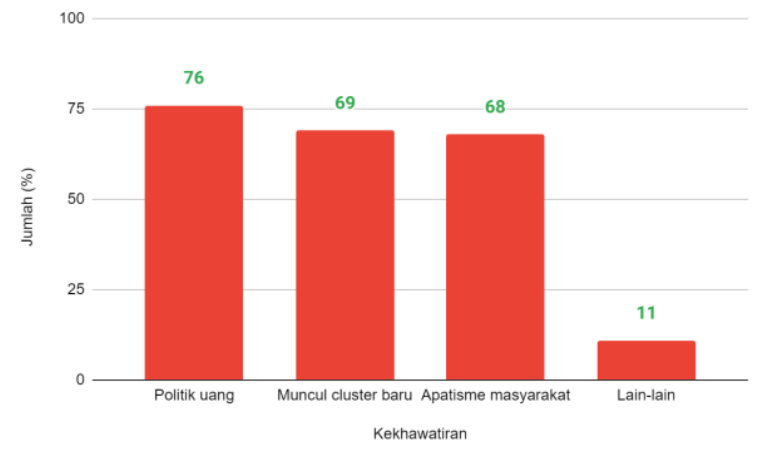

Gambar 3. Persentase kekhawatiran masyarakat terhadap berbagai potensi masalah yang mungkin muncul akibat Pilkada

Salah satu kekhawatiran masyarakat terhadap munculnya berbagai potensi masalah yang akan muncul pada pilkada iaiah politik uang atau money politics. Politik uang adalah uang yang ditujukan dengan maksud tertentu seperti contohnya untuk melindungi kepentingan bisnis dan kepentingan politik tertentu. Politik uang dapat terjadi ketika seorang kandidat meminta dukungan parpol tertentu atau membeli suara dari pemilih untuk memilihnya dengan imbalan yang bersifat finansial (Ananingsih, 2016). Berdasarkan hasil survei dari 100 orang responden diperoleh 76 orang khawatir akan muncul nya politik uang yang sering terjadi akan semakin mudah dilakukan oleh oknum masyarakat mengatasnamakan bantuan covid-19. Hal ini dikarenakan pada masa pandemi saat sekarang ini perekonomian masyarakat sangat kurang baik, sehingga jika ada oknum masyarakat memberi bantuan covid-19 dengan iming-iming untuk memilih calon kandidat dalam pemilu sangatlah mudah.

Menurut Cahyadi \& Hermawan (2019) berdasarkan aktor dan wilayah operasinya, politik uang dalam pilkada bisa dibedakan menjadi empat lingkaran sebagai berikut: (1) Lingkaran satu, adalah transaksi antara elit ekonomi (pemilik uang) dengan pasangan calon kepala daerah yang akan menjadi pengambil kebijakan/keputusan politik pasca pilkada; (2) Lingkaran dua, adalah transaksi antara pasangan calon kepala daerah dengan partai politik yang mempunyai hak untuk mencalonkan; (3) Lingkaran tiga, adalah transaksi antara pasangan calon dan tim kampanye dengan petugas-petugas pilkada yang mempunyai wewenang untuk menghitung perolehan suara; dan (4) Lingkaran empat, adalah transaksi antara calon dan tim kampanye dengan 
massa pemilih. Menurut Fitriyah (2012) Politik uang lingkaran empat ini biasa disebut dengan political buying, atau pembelian suara langsung kepada pemilih. Ada banyak macam bentuk political buying, yakni pemberian biaya transportasi kampanye, janji membagikan uang/barang, pembagian sembako atau semen untuk membangun tempat ibadah, "serangan fajar", dan lain-lain. Modus politik uang tersebut berlangsung dari pemilu ke pemilu, tidak terkecuali dalam pilkada dan praktik-praktik jual beli suara ini bukan semata-mata didasari oleh kebutuhan ekonomi sebagian besar pemilih, tetapi juga karena hal tersebut sudah lama berlangsung setiap kali ada pemilihan sehingga masyarakat menganggapnya sebagai sesuatu yang lumrah, meski mereka tahu bahwa hal itu melanggar ketentuan.

Menurut Wahyudi Kumorotomo (2009) ada berapa cara untuk melakukan politik uang dalam pilkada langsung, yakni: (1) Politik uang secara langsung bisa berbentuk pembayaran tunai dari "tim sukses" calon tertentu kepada konstituen yang potensial, (2) sumbangan dari para bakal calon kepada parpol yang telah mendukungnya, atau (3) "sumbangan wajib" yang disyaratkan oleh suatu parpol kepada para kader partai atau bakal calon yang ingin mencalonkan diri sebagai bupati atau walikota. Adapun politik uang secara tidak langsung bisa berbentuk pembagian hadiah atau doorprize, pembagian sembako kepada konstituen, pembagian semen di daerah pemilihan tertentu, dan sebagainya. Para calon bahkan tidak bisa menghitung secara persis berapa yang mereka telah habiskan untuk sumbangan, hadiah, spanduk, dan sebagainya, disamping biaya resmi untuk pendaftaran keanggotaan, membayar saksi, dan kebutuhan administratif lainnya. Tentunya dalam situasi pandemi ini, money politic sangat mungkin dilakukan. Oknum pelaku money politic dapat memberikan sejumlah uang atau logistik untuk membeli suara rakyat namun dengan kedok bantuan kepada masyarakat yang terdampak pandemi.

Di dalam UU No. 32 Tahun 2004 besaran sumbangan juga dibatasi, namun terkait pengaturannya tidak jelas dan sehingga mudah disalahgunakan. Lemahnya regulasi ini turut menimbulkan potensi masuknya dana ilegal kepada calon dan terjadinya politik uang dalam pilkada. Sumbangan politik uang terhadap kebutuhan dana dalam jumlah besar, terutama untuk komponen tidak resmi yang harus dikeluarkan kandidat, signifikan. Menurut Agustino \& Yusoff (2020) biaya besar yang dikeluarkan karena pilkada kerap disertai dengan praktek politik uang dan pemakelaran pencalonan kepala daerah. Politik uang dan pemakelaran inilah yang menyebabkan biaya pilkada semakin meningkat dan biaya demokrasi semakin tinggi.

Jumlah pemilih dapat menentukan tercapainya efektivitas kebijakan publik dalam pemilu. Pada masa pandemi seperti ini, dimungkinkan terjadinya penurunan jumlah pemilih di berbagai daerah yang mungkin disebabkan oleh ketakutan masyarakat akan tertular virus Covid-19. Penurunan jumlah pemilih dapat menyebabkan berbagai dampak, seperti tidak tercapainya efektivitas kebijakan publik bahkan hingga gagalnya proses sosialisasi politik yang berujung pada tingginya angka apatisme dalam partisipasi politik masyarakat. Dari 100 orang responden diperoleh $12 \%$ orang tidak peduli, $3 \%$ orang takut tertular, dan $45 \%$ orang belum memutuskan untuk ikut melakukan pemilihan umum atau tidak. Data tersebut dapat menggambarkan bahwa jiwa apatisme masyarakat semakin menurun karena masyarakat kurang merasakan urgensi pemilu yang sesungguhnya. Sosialisasi politik merupakan salah satu media yang penting untuk menumbuhkembangkan iklim demokrasi. Pemilu 
merupakan salah satu implementasi demokrasi yang sudah dimulai pasca pelengseran rezim orde baru. Namun, meningkatnya iklim di demokrasi melalui pemilihan langsung berbanding terbalik dengan kenyataan bahwa partisipasi politik masyarakat mengalami penurunan yang signifikan dari tahun ke tahun, ditambah lagi pada kondisi pandemi seperti ini. Terkait hal tersebut, apatisme masyarakat juga didukung oleh kefokusan masyarakat dalam mempertahankan perekonomiannya di pandemi Covid-19. Berdasarkan jurnal Aditia et al (2020) menyatakan analisis sensitivitas terhadap dampak pandemi Covid-19 yaitu menjelaskan bahwa melambatnya ekonomi global saat ini sangat berdampak terhadap pertumbuhan perekonomian Indonesia. Pandemi Covid-19 juga menimbulkan dampak yang mengerikan terhadap investasi dimana membuat masyarakat akan fokus memilih untuk sangat berhati-hati dalam membeli barang bahkan untuk melakukan investasi. Pandemi ini juga sangat mempengaruhi proyeksi pasar. Investor dapat cenderung untuk tidak berinvestasi dikarenakan berubahnya asumsi pasar dan tidak jelasnya supply chain (Pepinsky \& Wihardja, 2011). Permasalahan perekonomian masyarakat tentunya menjadi hal utama sebagai fokus masyarakat itu sendiri mengingat sudah jatuhnya nilai perekonomian bangsa Indonesia di pandemi Covid-19.

Cluster atau dapat juga dituliskan sebagai klaster, merupakan suatu istilah yang umum digunakan oleh publik di masa pandemi untuk menjelaskan suatu kelompok pasien positif Covid-19 yang saling berkaitan. Menurut Oktavia \& Hayati (2020), klaster merupakan suatu sistem untuk memberi kelas-kelas berdasarkan asal penyebaran virus. Penggunaan sistem ini memudahkan dalam identifikasi tingkat keparahan serta pembuatan peraturan dalam upaya menekan tingkat penyebaran. Berdasarkan hasil survei yang telah dilakukan pada 100 responden, sebanyak $69 \%$ responden memilih jawaban "Timbulnya cluster baru Covid-19". Hasil yang didapatkan ini menandakan bahwa besar kekhawatiran dari responden akan munculnya klaster baru pada pilkada serentak 2020. Kekhawatiran ini bukan tidak mendasar sebab rencana pemerintah akan tetap melaksanakan pemilihan dengan metode yang konvensional. Pengerumunan massa tentu menjadi salah satu potensi penyebaran virus. Sejak 21 Februari 2020 hingga 18 Oktober 2020 ada 73 negara yang menunda pemilu termasuk Indonesia dan 74 negara memutuskan tidak menunda pemilu dengan 58 negara telah melaksanakan pemilihan termasuk diantaranya Korea Selatan, Israel, Perancis, dan Amerika Serikat. Salah satu negara yang sukses dalam menangani penyebaran Covid-19 adalah Korea Selatan. April 2020 pemerintah Korea Selatan menjalankan kegiatan pemilu. Pelaksanaan pemilu di Korea Selatan dijalankan dengan prosedur dan peraturan ketat oleh pemerintahan dan petugas pemilu. Pada setiap pos pemilihan setiap pemilih akan disemprotkan desinfektan dan juga menjaga jarak saat mengantri. Setelah proses sterilisasi para pemilih kemudian di cek suhu tubuhnya dengan suhu tubuh melebihi 37 derajat celcius akan memilih pada tempat khusus yang berbeda. Pemilih diwajibkan memakai masker, pada pos pemilihan akan dibagikan sarung tangan plastik serta surat suara yang telah disterilkan amplopnya oleh desinfektan. Berdasarkan peraturan ketat dan kedisiplinan rakyatnya setelah proses pemilu selesai hanya terlapor empat orang positif Covid-19 (Kim, et al., 2020). Pelaksanaan pemilu lain juga telah dilakukan oleh pemerintahan Israel terlebih dahulu pada Maret 2020, pos-pos pemilihan juga dimodifikasi seperti tersedianya pos pemilihan khusus untuk yang sedang isolasi mandiri maupun di rumah sakit. Selain itu, komunikasi antara masyarakat dengan pemerintah juga terjalin baik dan menghindari munculnya disinformasi pada masyarakat khususnya terkait Covid-19. Pemilu 
pada Israel juga tidak memunculkan klaster penyebaran baru sebab hanya 20 orang positif Covid-19 pasca-melakukan pemilihan. Bahkan tercatat jumlah partisipasi pemilih meningkat dari pemilu sebelumnya yaitu $70 \%$ menjadi $71,5 \%$ dari total pemilih terdaftar sebanyak 6.394 .030 orang (Afek, et al., 2020). Kisah manis pemilu Korea Selatan dan Israel ternyata tidak berjalan baik di negara Prancis. Pemerintahan Prancis bersikukuh untuk tetap menjalankan pemilu pada bulan Maret 2020, seperti yang kita tahu bahwa pada periode tersebut awal mewabahnya Covid-19 di eropa termasuk Perancis. Sebanyak 19.863.660 pemilih dari total 44.650.472 rakyat Prancis di daerah metropolitan melakukan pemilihan secara langsung ke pos pemilihan. Upaya pemerintahan dalam menanggapi kekhawatiran masyarakat pemilih adalah dengan menutup seluruh fasilitas akademik dua hari setelah hari pemilu dan juga menutup seluruh fasilitas publik empat hari setelah pemilu untuk mencegah penyebaran Covid-19. Pada periode pasca-pemilu tercatat sekitar 4000 orang dirumahsakitkan berkaitan dengan Covid-19 akibat pemilu, jumlah ini setara dengan $15 \%$ jumlah orang yang dirumahsakitkan (Cassan \& Sangnier, 2020). Baru-baru ini telah pula dilaksanakan proses pemilu di negara adidaya Amerika Serikat. Proses pemilihan kali ini juga dikhawatirkan menimbulkan klaster baru di negara tersebut, hingga saat ini masih akan dianalisis dan diinvestigasi sebab tingkat penyebaran di Amerika Serikat juga terbilang masih tinggi.

Pada hakikatnya kekhawatiran masyarakat dapat dipahami sebab melihat sejauh ini tingkat penyebaran Covid-19 yang masih tinggi di Indonesia serta kurangnya penindakan ketat pada peraturan mengenai protokol kesehatan di area publik juga kedisiplinan masyarakat yang rendah. Pemilu pada Desember 2020 nanti memiliki dua kemungkinan yang dapat terjadi berkaitan dengan munculnya cluster baru, jika pemerintah dan masyarakat disiplin dalam menegakkan peraturan dan protokol kesehatan dengan ketat maka kemungkinan kesuksesan yang terjadi di Korea Selatan dan Israel dapat kita ulangi. Namun jika sebaliknya maka kejadian di Perancis atau bahkan lebih buruk dapat terjadi.

\section{Kesimpulan}

Berdasarkan hasil penelitian yang kami lakukan, didapatkan kesimpulan bahwa tingkat partisipasi masyarakat pada Pilkada Serentak 2020 menurun. Hal tersebut disajikan dalam bentuk data sebagai berikut. Berdasarkan tingkat pengetahuan masyarakat, 32 orang responden (32\%) tidak mengetahui sama sekali mengenai sistem maupun teknis pelaksanaan Pilkada 2020, 50 orang responden (50\%) sedikit mengetahui teknis pelaksanaan Pilkada 2020, dan 18 orang $(18 \%)$ telah mengetahui teknis pelaksanaan Pilkada 2020 . Berdasarkan tingkat antusiasme masyarakat terhadap Pilkada 2020, sebanyak 45 orang (45\%) belum memutuskan akan melakukan pencoblosan atau tidak, 40 orang $(40 \%)$ akan tetap melakukan pencoblosan, 12 orang (12\%) tidak peduli dengan pelaksanaan pilkada, dan 3 orang (3\%) menyatakan tidak akan melakukan pencoblosan karena takut terhadap penularan virus Covid-19. Berdasarkan kekhawatiran masyarakat terhadap masalah yang muncul akibat dilaksanakannya Pilkada menunjukkan bahwa dari 100 orang, 76 orang khawatir politik uang yang kerap terjadi akan semakin mudah dilakukan oleh oknum masyarakat dengan mengatasnamakan bantuan Covid-19, 69 orang khawatir akan munculnya cluster virus baru, 68 orang mengkhawatirkan akan 
berkurangnya jumlah pemilih sebagai bentuk respons ketakutan akan tertular virus, dan 11 orang lain menyatakan kekhawatiran atas kemunculan masalah lain.

Terlepas dari disahkannya pasal 210A Perpu no.2 tahun 2020 yang sekarang telah ditetapkan menjadi UU no.6 tahun 2020, keputusan dilaksanakannya pilkada pada kondisi pandemi merupakan kebijakan pemerintah dengan menimbang berbagai aspek. Penulis menawarkan beberapa solusi kepada masyarakat terkait potensi masalah yang telah di jelaskan pada bagian pembahasan. Solusi yang dapat penulis ditawarkan terkait masalah makin besarnya kemungkinan terjadi money politic dalam bentuk jual beli suara rakyat adalah dengan meningkatkan kesadaran masyarakat tentang efek jangka panjang yang mungkin terjadi jika perolehan suara jatuh pada pemimpin yang tidak kompeten dan mampu memegang amanah. Terkait potensi munculnya cluster baru, keengganan masyarakat untuk melakukan pemilihan di TPS secara luring merupakan ketakutan berdasar, namun kemunculan cluster baru dapat dicegah dengan kerjasama antar pemerintah dalam mengatur teknis \& standar operasional pelaksanaan pemilu dan masyarakat dengan mematuhi protocol kesehatan dengan baik.

\section{DAFTAR PUSTAKA}

Aditia D. D. Nasution, Erlina, dan Iskandar Muda. (2020). Dampak pandemi Covid-19 terhadap perekonomian Indonesia. Jurnal Benefita, 5(2), 212-224.

Afek, A., Leshem, E., Kaliner, E., Fast, D., \& Sadetzki, S. (2020). Upholding democracy in a global pandemic: the Israeli elections experience. Journal of Travel Medicine, 27(7), taaa162

Agustino, L., \& Yusoff, M. (2020). Pilkada dan Pemekaran Daerah dalam Demokrasi Lokal di Indonesia: Local Strongmen dan Roving Bandits. Jebat: Malaysian Journal of History, Politics \& Strategic Studies, 37, 86-104.

Ananingsih, S. (2016). Tantangan dalam Penanganan Dugaan Praktik Politik Uang Pada Pilkada Serentak 2017. Masalah-Masalah Hukum, 45(1), 49-57.

Ardiyanti, Dwi \& Zulian, Ibnu (2018). Korelasi identifikasi apatisme politik dengan kebijakan publik kota medan. Jurnal Power in International Relation, $3(1), 29-53$.

Aziz, N.M. (2009). Laporan akhir pengkajian hukum tentang pemilihan kepala daerah. diakses 13 November 2020. tersedia : https://bphn.go.id/data/documents/pkj_pilkada.pdf

Badan Pusat Statistik. (2019). Jumlah penduduk menurut kelompok umur dan jenis kelamin. diakses pada 13 November 2020. tersedia : https://www.bps.go.id/indikator/indikator/view data_pub/0000/api_pub/58/d a $03 / 1$

Cahyadi, R., \& Hermawan, D. (2019). Strategi Sosial Pencegahan Politik Uang di Indonesia. Jurnal Antikorupsi Integritas KPK RI, 5(1), 29-41. 
Cassan, G., \& Sangnier, M. (2020). Liberté, Egalité, Fraternité... Contaminé? Estimating the impact of French municipal elections on COVID-19 spread in France. medRxiv

Fitria, L., Neviyarni, Netrawati, Karneli, Y. (2020). Cognitive behavior therapy counseling untuk mengatasi anxiety dalam masa pandemi Covid-19. Al-Irsyad: Jurnal Pendidikan dan Konseling, 10(1), 23-29.

Fitriyah, M. (2012). Fenomena Politik Uang dalam Pilkada. Politika: Jurnal Ilmu Politik, 3(1), 5-14.

Kennedy, R., \& Suhendarto, B. P. (2020). Diskursus Hukum: Alternatif Pola Pengisian Jabatan Kepala Daerah di Masa Pandemi Covid-19. Jurnal Pembangunan Hukum Indonesia, 2(2), 188-204. https://doi.org/10.14710/jphi.v2i2.188-205

Kim, E. Y., Kim, E. K., Lee, M., \& Park, H. K. (2020). COVID-19 Public Health Measures During National Assembly Elections of the Republic of Korea. Osong Public Health and Research Perspectives, 11(4), 158.

Kumorotomo, Wahyudi, "Intervensi Parpol, Politik Uang Dan Korupsi: Tantangan Kebijakan Publik Setelah Pilkada Langsung", Makalah, disajikan dalam Konferensi Administrasi Negara, Surabaya, 15 Mei 2009

Lesmana, T. (2011). Politik uang dalam pilkada. Jakarta : LIPI.

Nasution, D. A. D., Erlina, Muda, Iskandar (2020). Dampak pandemi covid-19 terhadap perekonomian indonesia. Jurnal Benefita, 5(2), 212-224.

Oktavia, W., \& Hayati, N. (2020). Pola Karakteristik Ragam Bahasa Istilah Pada Masa Pandemi Covid 19 (CORONAVIRUS DISEASE 2019). Tabasa: Jurnal Bahasa, Sastra Indonesia, dan Pengajarannya, 1(1), 1-15.

Pepinsky, T. B., \& Wihardja, M. M. (2011). Decentralization and Economic Performance in Indonesia. Journal of East Asian Studies, 11(3), 337-371. Diakses dari https://doi.org/10.1017/S1598240800007372 pada 13 November 2020.

Susilo, A., Rumende, C. M., Pitoyo, C. W., Santoso, W. D., Yulianti, M., Herikurniawan, H., ... \& Chen, L. K. (2020). Coronavirus Disease 2019: Tinjauan Literatur Terkini. Jurnal Penyakit Dalam Indonesia, 7(1), 45-67.

Yuniar, R. W . (2020). Pilkada : tahapan pemilihan tetap dilaksanakan meski dikritik banyak pigak, Nadhatul ulama :'nyawa harus diprioritaskan'. BBC News Indonesia. diakses 13 November 2020. tersedia : https://www.bbc.com/indonesia/indonesia-54269158 